\title{
Criminal network investigation
}

\author{
Uffe Kock Wiil
}

\section{Editorial}

Criminal networks such as terrorist and organized crime networks pose a threat to both national and international security. Investigation of such networks by law enforcement and intelligence agencies is a complex and time-consuming task. The ability to understand and model such networks, to analyze and visualize such networks, to mine and forecast such networks, to predict and simulate such networks, and to effectively collaborate and share information about such networks are key factors in defeating them.

It is well known that the Internet is used for criminal activities such as terrorism. The Center for Terror Analysis, Danish Security and Intelligence Service wrote a report in 2008 that states: The Internet plays a significant and increasing role for militant extremists and terrorist groups that use this media to spread messages, communicate and carry out virtual training as well as for recruitment, logistic support and operational preparations [1]. The United Nations Office on Drugs and Crime (UNODC) wrote a report in 2012 that states: Technology is one of the strategic factors driving the increasing use of the Internet by terrorist organizations and their supporters for a wide range of purposes, including recruitment, financing, propaganda, training, incitement to commit acts of terrorism, and the gathering and dissemination of information for terrorist purposes [2]. Two papers of this special issue focus on matters related to the use of the Internet for criminal activities.

The first paper in this special issue by Torok (Developing an explanatory model for the process of online radicalization and terrorism) proposes a model for understanding the mechanisms and power relations that underlie the use of Internet services such as Facebook, YouTube, and Twitter for online radicalization and terrorism. The model is based on previous work by Foucault on psychiatric power [3].

The second paper in this special issue by BowmanGrieve (A psychological perspective on virtual communities supporting terrorist \& extremist ideologies as a tool for recruitment) examines the role of virtual communities as a tool for recruitment used by terrorist and extremist organizations. A case study looks at the how the Radical Right uses the Internet in their activities.

Many terrorist organizations are transnational in nature [2]. Hence, it is important to understand and predict the locational dynamics of such organizations. The third paper in this special issue by Desmarais and Cranmer (Forecasting the locational dynamics of transnational terrorism: a network analytic approach) proposes and evaluates a network analytic approach to predict the geopolitical sources and targets of terrorism.

Software tools play an increasing role in criminal network investigation [4]. Software tools can help support and (semi) automate some of the complex knowledge management processes involved in criminal network investigation (collection, processing, synthesis, sense-making, dissemination, etc.). The fourth and final paper in this special issue by Petersen and Wiil (CrimeFighter Investigator: Integrating synthesis and sense-making for criminal network investigation) presents a new software tool dedicated to support criminal network investigation.

Received: 7 April 2014 Accepted: 7 April 2014

Published: 11 Apr 2014

\section{References}

1. Center for Terror Analysis, Danish Security and Intelligence Service: The role of the Internet in relation to radicalisation and terrorism. Copenhagen, Denmark; 2008. https://www.pet.dk/CTA/media/CTA/Microsoft_Word_-_Internettets_ rolle_i_relation_til_radikalisering_og_terrorisme_-_final_15_9_08.ashx

2. United Nations Office on Drugs and Crime (UNODC): The use of the Internet for terrorist purposes. New York; 2012. http://www.unodc.org/documents/ frontpage/Use_of_Internet_for_Terrorist_Purposes.pdf

3. Foucault M: Lectures at the College de France 1973-1974. In Michel Foucault: psychiatric power. Edited by LaGrange J. New York: Palgrave MacMillan; 2006. Davidson Al (Series Editor).

4. U K Wiil: Issues for the next generation of criminal network investigation tools. In Proceedings of the European Intelligence and Security Informatics Conference (EISIC 2013). Uppsala, Sweden: IEEE Computer Society; 2013:7-14.

10.1186/2190-8532-3-1

Cite this article as: Wiil: Criminal network investigation. Security Informatics 2014, 3:1 